\title{
Effects of ectostriatal lesions, Wulst lesions and hemispherectomy upon visual discrimination of food in pigeons
}

\author{
WATANABE, Shigeru \\ Department of Psychology, Keio University \\ Mita 2-15-45, Minato-ku, Tokyo 108, Japan
}

Using an operant procedure, pigeons were trained on a visual discrimination between four edible and non-edible objects. Experiment I indicates that performance on this task was not affected by lesions of either visual Wulst or ectostriatum. In Experiment II the effects of hemispherectomy, combined with monocular visual occlusion were examined. No deficits were seen when subjects were tested using the eye contralateral to the intact hemisphere, but deficits were seen when they used the eye contralateral to the ablated hemisphere. The results suggest that either Wulst or ectostriatum is sufficient to mediate visual discrimination of food, but damage to both structures significantly impairs this discriminative behavior.

Key words: food recognition, hemispherectomy, brain lesions, visual discrimination

【要 旨】 ハトに 4 種類の餌（穀物）と4 種類の食べられないもの（石，ネジなど）の弁別をオペラント 条件づけより訓練した後, 視床経由視覚系の Wulst, 視蓋経由視覚系の外線状体を両側破壊した. しか し, どちらの昜合も顕著な認知障害は見られなかった。. 次に, Wulst, 外線状体をふくむ大弾半球摘除を一 側性に行った。 その結果, 摘除半球と対側単眼を使用させた場合にのみ顕著な食物の認知障害が認められ

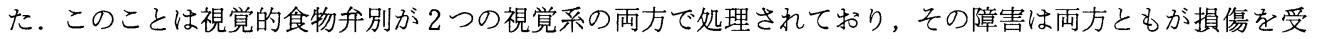
けた時にのみ発現することを示唆する.

\section{INTRODUCTION}

The visual system of birds includes both a thalamofugal and a tectofugal division, both projecting ultimately to the telencephalon. The former includes projections from the retina to the nucleus opticus principalis thalami (OPT) and then to a group of structures in the telencephalon collectively referred to the visual Wulst that includes the hyperstriatum accessorium(HA), hyperstiatum intercalatus superior (HIS) and the hyperstiatum dorsale (HD). The latter includes a projection from the retina to the optic tectum and then to the nucleus rotundus of the thalamus that, in turn, projects upon the core region of the ectostriatum(ECT).

The analysis of visual deficits following brain lesions in pigeons has primarily used psychophysical procedures and discriminative behaviors (Bessette \& Hodos, 1989; Hodos, 1976; Hodos et al, 1986; Jäger, 1990; Kertzman \& Hodos, 1988; Powers et al, 1982; Riley et al, 1988). More cognitive behavior has rarely been 
used in lesion studies of the pigeon(Delius \& Holland, 1987; Jarvis, 1974; Shimizu \& Hodos, 1989 ). Although there have been many studies of avian conceptual behavior (Bhatt \& Wasserman, 1989; Bhatt et al, 1988; Edwards \& Honig, 1987; Herrnstein \& Loveland, 1964; Honig \& Stewart, 1988; Lea, 1984; Morgan et al, 1976; Poole \& Lander, 1971; Roberts \& Mazmanian, 1988; Wasserman et al, 1988), brain regions mediating such cognitive behavior have not been well examined.

Watanabe (1991a) trained pigeons on "artificial” (triangles vs. three randomly arranged lines generated by computer graphics) or "natural" (food vs. non-food) visual discrimination tasks. Ectostriatal damage caused deficits in the artificial but not in natural concept tasks. Furthermore, arbitrary classification of natural objects including both food and non-food were disrupted by the ectostriatal lesions. These results suggest that the ectostriatum has a critical role in artificial discrimination but not in natural discrimination. The brain region that mediates the visual food discrimination was, however, not clarified in these results.

In the present study, a similar approach was used to try to identify telencephalic structures crucial for visual food discrimination. Because the ectostriatal lesion did not cause severe deficits in food discrimination, one candidate should be Wulst. In Experiment I, the effects of Wulst or ectosrtiatal lesions alone were examined while Experiment II examined the effects of unilateral hemispherectomy to figure out role of the telencephalon in the visual food discrimination.

\section{EXPERIMENT I}

In this experiment two telencephalic terminals of the visual system were examined. The subjects were trained to discriminate food and non-food, then their ectostriatum or visual Wulst was bilaterally damaged.

\section{METHODS}

Subjects Eight pigeons (Columba livia) were used. They were maintained at 80 percent of their free-feeding weights throughout the experiment.

Apparatus An experimental chamber was an operant chamber for the pigeon $(30 \times 30 \times 30 \mathrm{~cm})$ with a single key. A rectangular clear glass pecking key $(2.5 \times 4.5 \mathrm{~cm})$ was mounted on a front panel of an operant chamber. The key was located $18 \mathrm{~cm}$ above the floor. An aperture for the food hopper was below the key. A motor-drive belt conveyer with 40 cubicles $(4 \times 7 \times 7 \mathrm{~cm})$ was placed just behind the key. Ceilings and one side of the walls of the cubicles were removed so that a pigeon in the chamber could see inside a cubicle just in front of the key but could not see the other cubicles. A cubicle in front of the key was illuminated by a small lamp (2.5 Lux). Continuous noise from a fan was presented during the experiment. The experiment was controlled by a microcomputer system.

Stimulus Four kinds of grains (corn, pea, buckwheat and wheat) and four non-edible objects (stone, twig, yellow paper clip and nut) were placed in the cubicles.

Procedure Every subject was trained to peck the key by an autoshaping procedure. A VI schedule then was introduced to maintain stable responding. After the subjects showed stable responding they were divided into two groups: the food $\mathrm{S}+$ group (4 birds) and the non-food $\mathrm{S}+$ group (4 birds). All groups were trained with the same eight kinds of objects, but the four kinds of grains were the $\mathrm{S}+$ for the food $\mathrm{S}+$ group while the four non-food objects were the $\mathrm{S}+$ for the non-food $\mathrm{S}+$ group. Eight stimuli were presented five times randomly in one training session. Each stimulus presentation lasted $30 \mathrm{sec}$ followed by a five sec blackout period. During presentation of $\mathrm{S}+$ reinforcement was available on a Variable Interval 30 
sec schedule and the $\mathrm{S}-$ presentation was associated with extinction(multiple VI30"-extinction schedule).

The discrimination training continued until the subjects showed above 90 percent discrimination ratio, calculated by dividing the number of responses to $\mathrm{S}+$ by the total number of responses, on two successive sessions. After the subjects reached the criterion, they received brain lesions. Following five days of recovery period the subjects were retrained until they reached the criterion again.

Surgery The targets of the brain lesions were the ectostriatum or the Wulst (HA, HIS and HD). The animals were anesthetized by an intramuscular injection of ketamine (Ketalar 50) and were fixed in a stereotaxic apparatus. A local anesthetic (Xylocaine) then was injected into the incision site. An electrode with a thermosensor was inserted into the brain according to coordinates obtained from a standard pigeon atlas (Karten \& Hodos, 1967), and lesions were made with a radio-frequency lesion maker (Radionix). Temperature at a tip of the electrode was kept at 70 degrees centigrade for $60 \mathrm{sec}$ to produce damage. All lesions were bilateral and the electrode was inserted into two different positions for the ectostriatal lesions. The electrode fixed on a tilted manipulator was inserted and the current was passed three times at different distance from the insertion point to make Wulst lesions.

Histology After completion of behavioral experiment the animals were injected intravenously with pentobarbital, then were perfused with normal saline followed by Heidenhein's solution without mercuric chloride. Then the brains were removed from the skull and were kept in $10 \%$ formal-saline solution for one week or more, after which the brains were processed, embedded in paraffin and cut at $10 \mu \mathrm{m}$. Every tenth section was mounted, counter-stained with cresyl violet and luxol fast blue and examined microscopically. Brain damage was reconstructed on images of pigeon's brain atlas displayed on a computer controlled TV screen, and a computer program was used to calculate the volume of the damage.

\section{RESULTS AND DISCUSSION}

Table 1 summarizes the quantitative results of histological reconstructions and Figure 1 presents examples of the reconstruction.

Figure 2 shows the correct percentage responses in the final session before the lesions and those in the first session after the lesions. $\mathrm{S}+$ was food for pigeons $\mathrm{C} 21$ and E24 in the ectostriatal lesion group and A32 and D24 in the Wulst lesion group. Clearly neither the Wulst lesions nor the ectostriatal lesions caused deficits in discrimination of the foods. The numbers of the sessions required to reach the criterion before and after the lesions are presented also in Figure 2. There was no significant difference in acquisition between the food $\mathrm{S}+$ and non-food $\mathrm{S}+$ tasks. Although one bird with the ectostrital damages required some retraining sessions, most of the birds did not.

Table 1 Percent damages to each structure.

\begin{tabular}{|c|c|c|c|c|c|c|c|c|}
\hline & \multirow{2}{*}{$\begin{array}{l}\text { Left } \\
\text { HA }\end{array}$} & \multicolumn{3}{|c|}{ Hemisphere } & \multicolumn{4}{|c|}{ Right Hemisphere } \\
\hline & & $H D$ & HIS & & $\mathrm{HA}$ & $\mathrm{HD}$ & HIS & \\
\hline A11 & 22 & & 3 & & 27 & & 18 & \\
\hline A32 & 23 & 30 & 44 & & 23 & 18 & 27 & \\
\hline D24 & 20 & 19 & 12 & & 18 & 31 & 16 & \\
\hline \multirow[t]{3}{*}{ E11 } & 37 & 4 & 26 & & 27 & 25 & 33 & \\
\hline & Left & \multirow{2}{*}{\multicolumn{3}{|c|}{$\begin{array}{l}\text { Hemisphere } \\
\text { CoreNeo HV }\end{array}$}} & \multirow{2}{*}{\multicolumn{4}{|c|}{$\begin{array}{l}\text { Right Hemisphere } \\
\text { Belt CoreNeo HV }\end{array}$}} \\
\hline & Belt & & & & & & & \\
\hline $\mathrm{C} 21$ & 58 & 77 & 1 & & 50 & 60 & 1 & \\
\hline E12 & 56 & 91 & 3 & 2 & 48 & 85 & 2 & 1 \\
\hline E13 & 51 & 85 & 2 & 2 & 100 & 89 & 5 & \\
\hline E24 & 28 & 73 & 2 & & 37 & 67 & 4 & \\
\hline
\end{tabular}

Belt: belt area of ectostriatum; Core :core part of ectostriatum; HA:hyperstriatum accessorium; HD: hyperstriatum dorsale; HIS :hyperstriatum intercalatus superior; HV: hyperstriatum ventrale; Neo: neostriatum. 

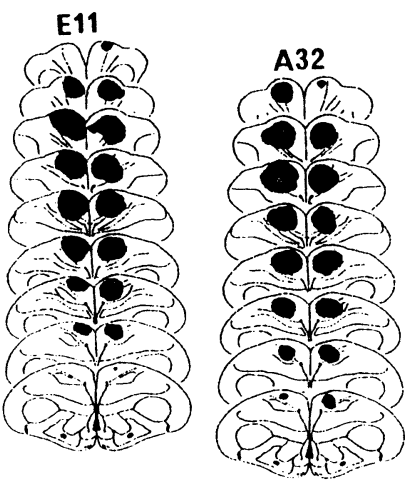
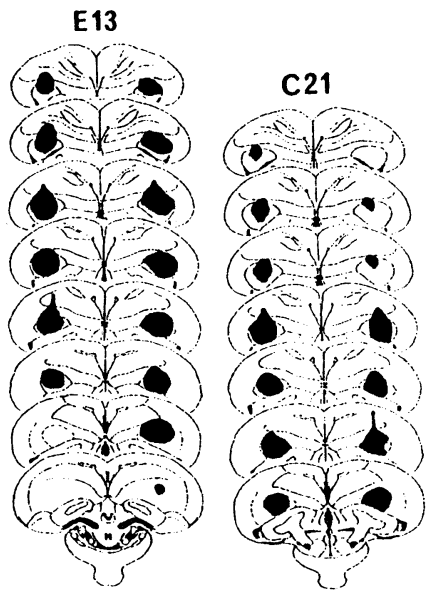

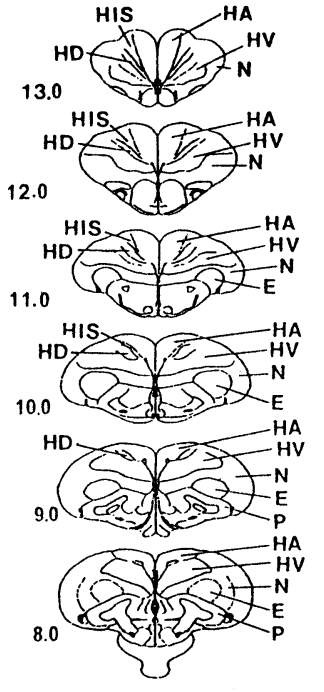

Fig. 1. Examples of reconstruction. Dark area indicates damaged region. ECT: Ectostriatum, HA: Hyperstriatum accessorium, HD: Hyperstriatum dorsale, HIS: Hyperstriatum intercalatus superior, HV: Hyerstriatum ventrale, NE: Neostriatum.
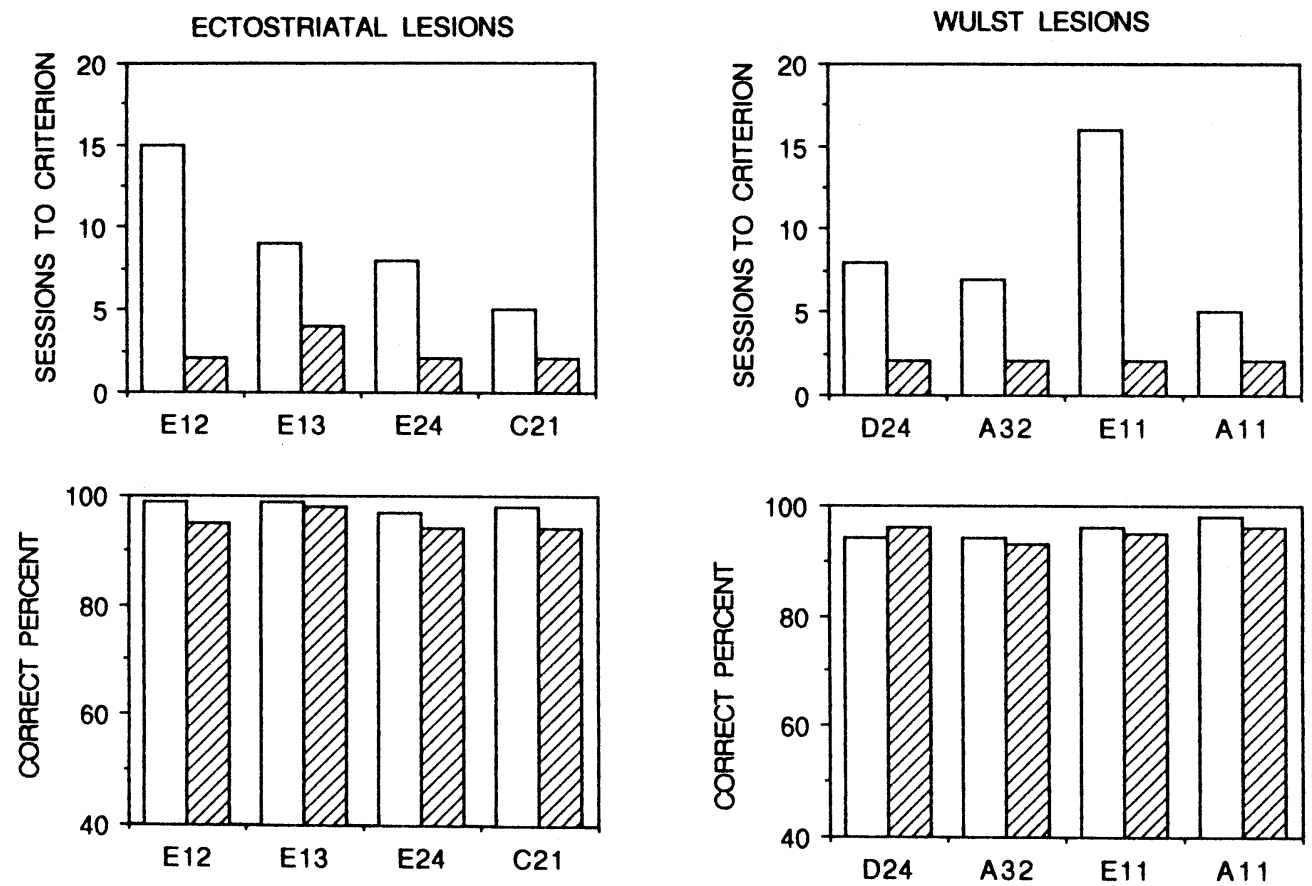

Fig. 2. Effects of lesions on food discriminations. Upper panel: The number of sessions required to attain the criterion before and after the surgery. The number includes the last two sessions of above 90 percentage correct response. Lower panel: Percentage correct responses in the last session before surgery and the first session after surgery. Open and shaded bars indicate learning before lesions and after lesions respectively. 
The absence of deficits in the food discrimination is consistent with previous studies of Wulst lesion effects on visual discriminations (Hodos et al., 1973) as well as with the finding that such lesions do not impair a grain/pebble discrimination on a consummatory task (Jäger, 1990). The absence of impairment after ectostriatal lesions in the present study is not consistent with the previous finding of deficits in visual intensity and pattern discriminations (Bassette \& Hodos, 1989) but agrees with our previous results using a food discrimination task (Watanabe, 1991a). As described in introduction, Watanabe (1991a) reported deficits in discrimination of an artificial pattern discrimination after the ectostriatal lesions. Numerical analysis of the damaged volume using a weighted index of bilateral brain damage (Hodos \& Bobko, 1984) did not give a significant difference between the food discrimination group and the artificial pattern discrimination group. Thus, no deficits in the food discrimination should be resulted from the nature of discrimination task. The lesion volumes in the present study were similar to those in the previous study (Watanabe, 1991a). The subjects may use a variety of cues to make the food discrimination. Besides, as described in the introduction a visual concept of food may be well established prior to training.

\section{EXPERIMENT II}

Experiment I showed that neither Wulst nor ectostriatum is necessary for the visual food discrimination. Recently, DeSouza-Calena et al. (1990) showed that bilaterally hemispheretomized pigeons could maintain the key pecking behavior acquired prior to the hemispherectomy, indicating that the telencephalon is not critical for visual orientation or motor output. The results of Experiment I may suggest that some region below the telencephalon mediates food discriminations. Because pigeons have no interhemispheric commissure transmitting visual information at the telencephalon, monocular viewing conditions after the hemispherectomy produces reversible "visual decerebration" (Jäger et al., 1992). In Experiment II a combination of monocular occlusion and unilateral hemispherectomy was employed to examine processing in the telencephalon.

\section{METHODS}

Subjects Four experimentally naive pigeons were used.

Apparatus The apparatus for operant conditioning was identical with that used in Experiment I .

Procedure The subjects were divided into food $\mathrm{S}+$ and non-food $\mathrm{S}+$ group. Using the same procedure as in Experiment I, subjects were trained to discriminate food from non-food objects. Food was S+ for C34 and D32, and non-food was S+ for G12 and G31. Then, performance with monocular condition was examined. Double thickness black tape was patched on the one eye of the subject and the subjects was trained under the daily training condition. Performance with the other eye was examined on the next day.

Then the subjects received the surgery. Following five days of recovery period, the birds were trained alternatively with each monocular condition. Such monocular retraining continued for at least three sessions with each viewing condition.

Surgery The subject was anesthetized and fixed in the stereotaxic apparatus and a hole for the aspiration was made in the skull. Then the dura was cut and a glass pipette for aspiration was gently inserted into the brain tissue under a microscope. The hyperstriatum, ectostriatum and the most of neostriatum were removed but most of the archistriatum and paleostriatum was kept intact. After the aspiration gellfoam was inserted. Right and left 
hemispherectomy were balanced across birds (2 right, 2 left).

Histology Following the completion of the experiment, subjects were scarified and the tissues were processed for reconstruction as in Experiment I .

\section{RESULTS AND DISCUSSION}

Figure 3 presents histological reconstructions. Pigeon C34 had the most intensive damages and the D32 the slightest. The posterior part of the ectostriatum was not directly damaged in G31 and D32. They kept their lateral part of the telencephalon intact. All birds showed cell loss in the nucleus rotundus and OPT ipsilateral to the ablation.

Figure 4 presents individual performance before and after the hemispherectomy. Prior to surgery, there was no significant difference in performance between the two monocular

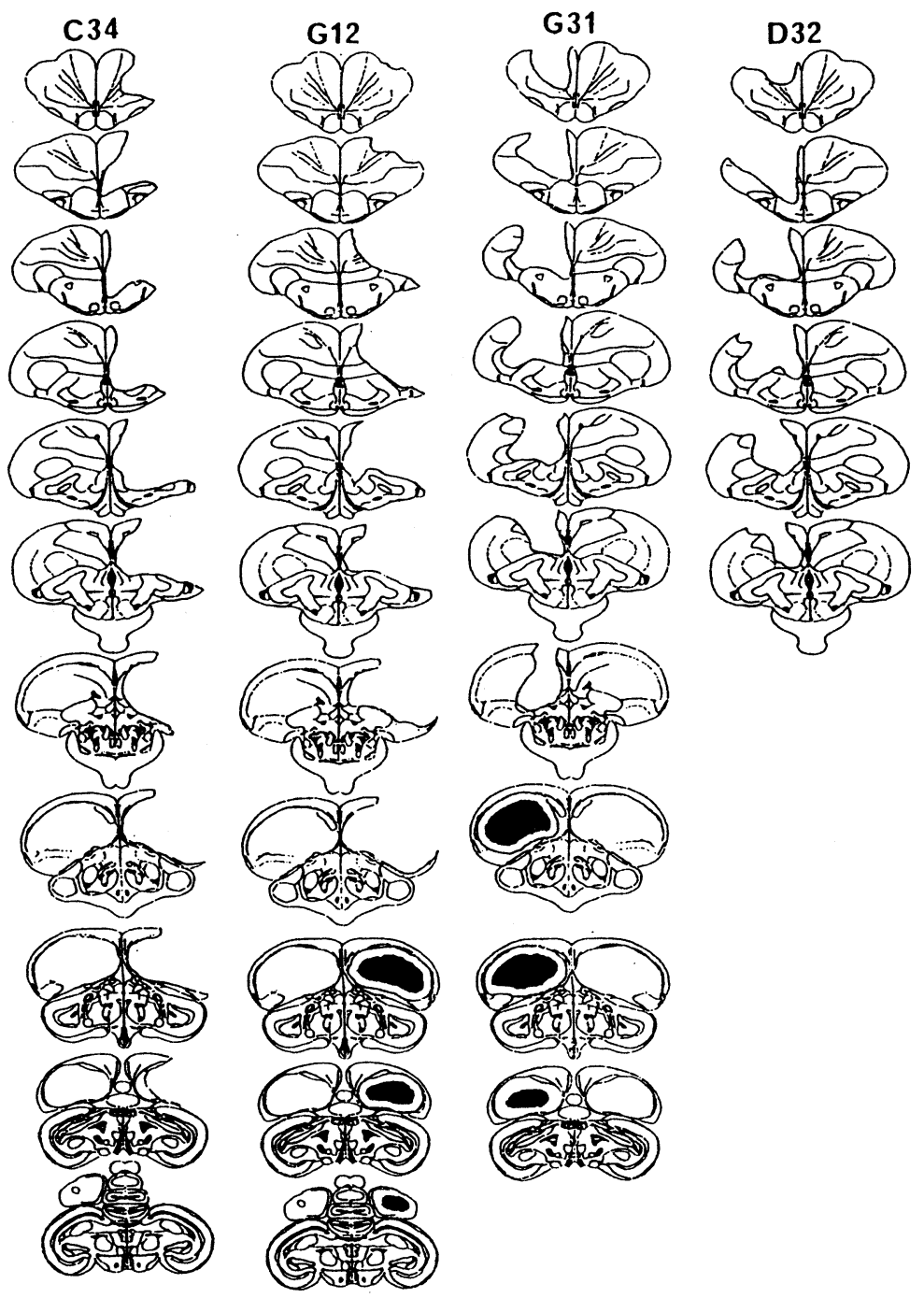

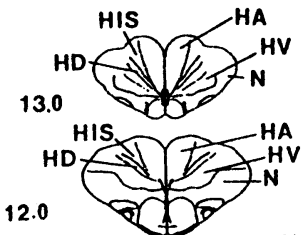
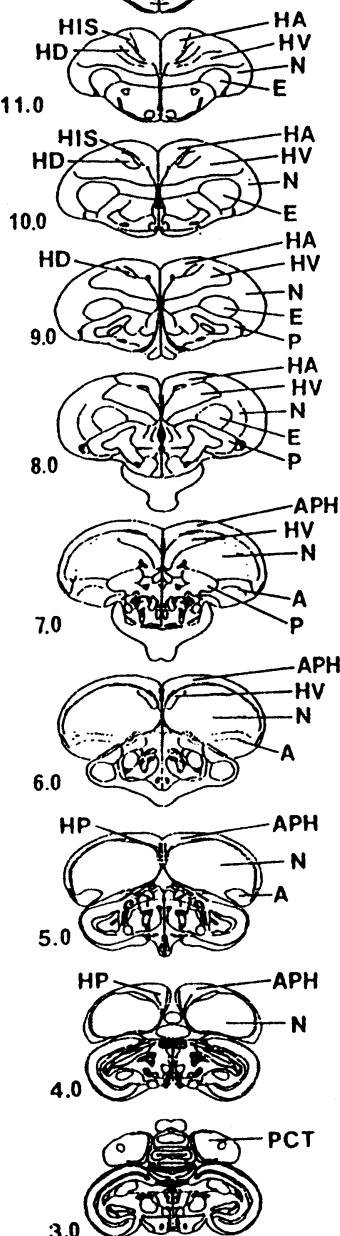

Fig. 3. Reconstructions of the hemisphe rectomy. Dark area indicates damaged region. 
conditions. After hemispherectomy, occlusion of the eye contralateral to the hemispherectomy did not impair pecking responses but significantly disrupted discriminative behavior. The difference between performance with the two eyes in the hemispherectomized condition was statistically significant (correlated $t$-test, $t=9.7$, $\mathrm{df}=4, \mathrm{p}<0.001) . \quad \mathrm{D} 32$ and $\mathrm{G} 12$ showed wide range of fluctuations in their discrimination with the eye contralateral to the damaged hemisphere. Combining unilateral hemispherectomy with occlusion of the eye contralateral to the occluded hemisphere, Jäger et al. (1992) observed that unilaterally hemispherectomized pigeons, viewing with the eye contralateral to the ablated hemisphere, are severely impaired on several measures of pecking efficiency, including consummatory pecking, a seed/pebble discrimination and a conditioned peck location
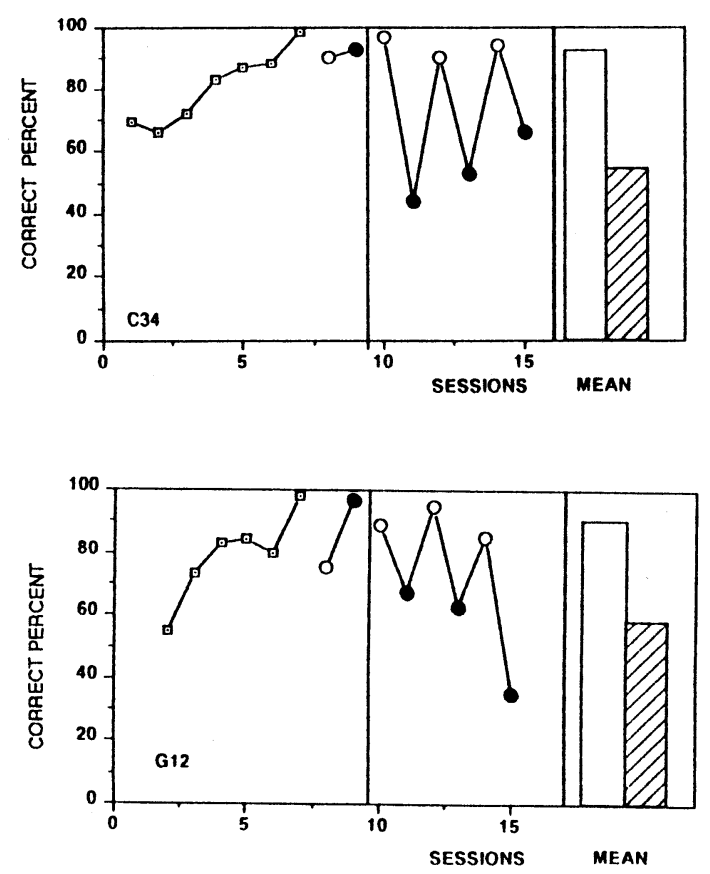

task. The present results are consistent with those finding and the finding of $\mathrm{Nau}$ and Delius (1981) of impairment of visual pattern discriminations in birds with large telencephalic (mostly Wulst) lesions tested with the eye contralateral to the lesion. Because the lesions in the present experiment damaged both Wulst and ectostriatum, the results suggest an important role for the telencephalon in prosessing the visual discrimination of food. The observation that the pigeons did not decrease their pecking rate after the hemispherectomy suggests that the deficits were not sensory-motor deficits but cognitive deficits. Previous studies have shown no severe deficits in visual discrimination by Wulst alone lesions (Hodos, 1976; Hodos et al, 1973). The present results of Experiments I and II suggest that the Wulst substitutes discriminative function of the ectostriatum when
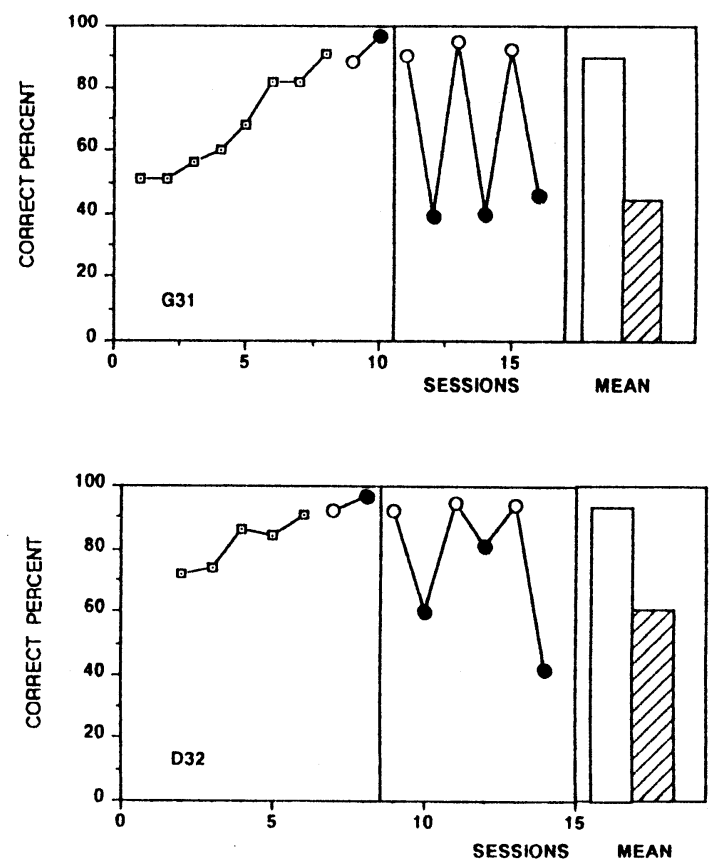

Fig. 4. Discrimination learning curves. The subjects were tested with each eye before surgery for two sessions, then after the surgery they were trained under each viewing condition for six sessions. Squares indicate binocular condition. Open and closed circles indicate monocular condition with the eye ipsilateral and contralateral to the ablated hemisphere respectively. The bar graph shows mean percentage correct after the surgery. Open and shaded bars represent performance with the eye ipsilateral and contralateral to the ablated hemisphere. 
the ectostriatum was damaged. That is, the Wulst has some discriminative function.

Although pigeons have an almost completely crossed optic chiasm, they have visual re-crossing commissures at the diencephalic level. Previous studies of interocular transfer of visual discriminations in birds with commissure sections or rotundal lesions suggest a bilateral read-out of lateralized memory (Watanabe, 1985; 1988; Watanabe 1991b). If this were the case, a visual memory of food should have been established in both hemispheres by binocular training and should be accessible from the intact hemisphere even when the eye contralateral to the ablated hemisphere was used. The present results are not consistent with this explanation of interocular transfer. The discrepancy may be related to difference in the original training (monocular vs. binocular). More ever, hemispherectomy in the present experiments caused cell loss in the nucleus rotundus ipsilateral to the ablated hemisphere. Avian species do not have commissures connecting the two sides of telencephalon except for the anterior commissure that does not have visual function. Thus, the visual pathway accessing the one side of telencephalon must go through the diencephalon, mostly the nucleus rotundus. Secondary damages to the nucleus rotundus may disturb this access of ipsilateral memory through diencephalic commissure.

\section{CONCLUSION}

The results of the two experiments demonstrate that 1) neither Wulst nor ectostriatum alone is crucial for visual discrimination of food, but 2) extensive damages to one hemisphere abolish the visual food discrimination.

It is suggested, that the two telencephalic visual structures, Wulst and ectostriatum, compensate for each other.

\section{ACKOWLEDGEMENTS}

The author wishes to express his thanks to P. Zeigler for his valuable comments and corrections on this manuscript. This research was supported by a Grand-in-Aid for Scientific Research (No. 6140019).

\section{REFERENCES}

Bessette, B. B., \& Hodos, W. 1989 Intensity, color, and pattern discrimination deficits after lesions of the core and belt regions of the ectostriatum. Vis. Neurosci., 2, 27-34.

Bhatt, R. S., \& Wasserman, E. A. 1989 Secondary generalization and categorization in pigeons. J. Exp. Anal. Behav., 52, 213-224.

Bhatt, R. S., Wasserman, E. A., Reynolds, W. F. and Knauss, K. S. 1988 Conceptual behavior in pigeons: Categorization of both familiar and novel examples from from classes of natural and artificial stimuli. J. Exp. Psychol.: Anim. Behav. Proc., 14, 219-234.

Delius, J. D. \& Hollard, V. D. 1987 Orientation invarience of shape recognition in forebrainlesioned pigeons. Behav. Brain Res., 23, 251-259.

DeSouza-Calena, C. M. Z, Britto, L. R. G. and Ferrari, E. A. de Moraes. 1990 Key pecking operant conditioning in detelencephalated pigeons (Columba livia). Behav. Brain Res., 38, 223-231.

Edwards, C. A. \& Honig, W. K. 1987 Memorization and "feature selection" in the acquisition of natural concepts in pigeons, Learn. and Motiv., 18, 235-260.

Herrnstein, R. J. and Loveland, D. H. 1964 Complex visual concepts in the pigeon.

Science, 146, 549-551.

Hodos, W. 1976 Vision and the visual system: A bird's eye view. In J. M. Sprague \& A. M. Epstein(Eds), Progress in psychology and physiological psychology, New York: Academic Press Pp. 29-62.

Hodos, W., and Bobko, P. 1984 A weighted 
index of bilateral brain lesions. J. Neurosci. Meth., 12, 43-47

Hodos, W., Karten, H. J. \& Bonbright, J. C. 1973 Visual intensity and pattern discrimination after lesions of the thalamofugal visual pathway in pigeons. J. Comp. Neurol., 148, 447-468.

Hodos, W., Weiss, S. R. B., \& Bessette, B. B. $1986 \mathrm{Siz}$ ethreshold changes after lesions of the visual telencephalon in pigeons. Behav. Brain Res., 21, 203-214.

Honig, W. K. \& Stewart, K. E. 1988 Pigeons can discriminate locations presented in pictures. J. Exp. Anal. Behav., 50, 541-551.

Jäger, R. 1990 Visuomotor feeding perturbation after lateral telencephalic lesions in pigeons. Behav. Brain Res., 40, 73-80.

Jäger, R., Arends, J. J. A., Schall, U. \& Zeigler, P. 1992 The visual forebrain and eating in pigeons. Brain, Behav. Evol., 39, 153-168.

Jarvis, D. D. 1974 Visual discrimination and spatial localization deficits after lesions of the tectofugal pathway in pigeons. Brain, Behav. Evol., 9, 195-228.

Karten H. \& Hodos, W. 1967 A stereotaxic atlas of the brain of the pigeon(Columba livia). The Johns Hopkins Press, Baltimore.

Kertzman, C., \& Hodos, W. 1988 Size-difference thresholds after lesions of thalamic visual nuclei in pigeons. Vis. Neurosci, 1, 83-92.

Lea, S. E. G. 1984 In what sense do pigeons learn concept? In H. L. Roitblat., T. G. Bever, \& H. Terrace (Eds), Animal cognition, Hillsdale, NJ: Erlbaum Pp. 263-276.

Morgan, M. J., Fitch, M. D., Holman, J. G., \& Lea, S. E. G. 1976 Pigeons learn the concept of an "A". Perception, 5, 57-63.

Nau, F. and Delius, J. D. 1981 Discrepant effects of unilateral and bilateral forebrain lesions on the visual performance of pigeons. Bahav. Brain Res., 2, 119-124.

Poole, J. \& Lander, D. G. 1971 The pigeon's concept of pigeon. Psychon. Sci., 25,
157-158.

Powers, A. S., Halasz, F., \& Williams, S. 1982 The effects of lesions in telencephalic visual areas of pigeons on dimensional shifting. Physiol. Behav., 29, 1099-1104.

Riley, N. M., Hodos, W., \& Pasternak, T. 1988 Effects of serial lesions of telencephalic components of the visual system in pigeons. Vis. Neurosci., 1, 387-394.

Roberts, W. A. \& Mazmanian, D. S. 1988 Concept learning at different levels of abstraction by pigeons, monkeys, and people. J. Exp. Psychol: Anim. Behav. Proc., 14, 247-260.

Shimizu, T. \& Hodos, W. 1989 Reversal learning in pigeons: Effects of selective lesions of the Wulst. Behav. Neurosci., 103, 263-273.

Wasserman, E. A., Kiedinger, R. E., \& Bhatt, R. S. 1988 Conceptual behavior in pigeons: Categories, subcategories, and pseudocategories. J. Exp. Psychol: Anim. Behav. Proc., 14, 235-246.

Watanabe, S. 1985 Interhemispheric transfer of visual discrimination in pigeons with supra chiasmatic decussation (DSO). Behav. Brain Res., 17, 163-170.

Watanabe, S. 1988 Effects of unilateral thalamic lesion upon interocular transfer of visual discrimination learning in the pigeon I. Lesions in the trained hemisphere (memory deficits). Behav. Brain Res., 29, 259-265.

Watanabe, S. 1991a Effects of ectostriatal lesions on natural concept, pseudoconcept and artificial pattern discrimination in pigeons.

Vis. Neurosci., 6, 497-506.

Watanabe, S. 1991b Effects of unilateral thalamic lesion upon interocular transfer of visual discrimination learning in pigeons. II. Lesions in the untrained hemisphere (sensory deficits). Behav. Brain Res., 43, 103-108.

\section{APPENDIX}

The visual system of the pigeon 
The pigeon has two major visual pathways, the thalamofugal pathway (analogous to mammalian geniculo-striatal pathway) and the tectfugal pathway (analogous to mammalian tecto-thalamo-extrastriate pathway). In the former pathway, the retina projects to the several thalamic nuceli, including the nuclei lateralis anterior (LA), dorsalateralis naterior pars lateralis (DLL), the dorsolateralis anterior pars magnocellularis (DLAmc). This group of nuceli is named the principal optic nucelei of the thalamus (OPT) that is comparable to the mammalian LGNd. The OPT send projection to the Wulst, a dorsomedial elevation of the avian telecephalon. The Wulst has a laminated structure. The hyperstriatum accessorium (HA), the intercalated neclelus of the hyperstriatum (IHA), the hyperstriatum intercalatus superior(HIS) and the hyperstriatum dorsale (HD). The IHA is the major recipient of the thalamic projection and the HA send descending projections to the OPT, the tectum (Teo) and GLv. The efferents of HA are observed in the lateral parts of the lobus parolfactorius (LPO). The HIS and the HD projects to the anterior lateral portion of the hyperstriatum ventrale (HVAL) that send projections to the core of the ectostriatum (EC).

In the tetofugal pathway, the retinal projection terminates in laminae 2 through 7 of the optic tectum. The layer 3 projects to the nucleus rotundus (RT) that is comparable to the mammalian pulvinar. The EC receives a projection from the RT. Thus, the EC has a similar properties of the layer 4 of the mammalian visual cortex. The EC send a projection to peri-ectostriatal belt (EP). The EP projects to the lateral neostriatal intermedium (NIL) that send a projection to the archistriatum intermedium (AI). The AI projects on Teo. The EP and NIL are comparable to the layers 2 and 3 of the mammalian cortex, and $\mathrm{AI}$ is comparable to the layer 6 .

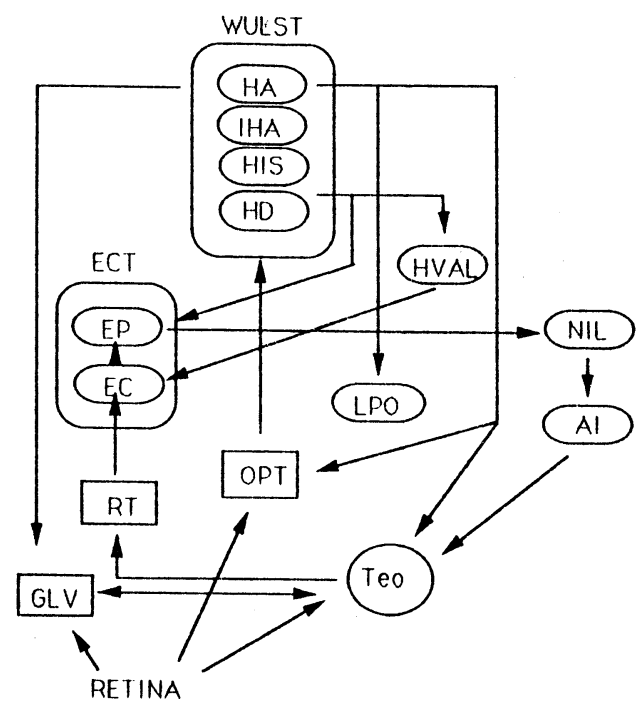

